\title{
27-day cycles in human mortality: Traute and Bernhard Düll
}

\author{
F. Halberg ${ }^{1}$, N. Düll-Pfaff ${ }^{2}$, L. Gumarova ${ }^{1,3}$, T. A. Zenchenko ${ }^{4}$, O. Schwartzkopff ${ }^{1}$, E. M. Freytag , $^{5}$, \\ J. Freytag ${ }^{5}$, and G. Cornelissen ${ }^{1}$ \\ ${ }^{1}$ Halberg Chronobiology Center, University of Minnesota, Minneapolis, MN, USA \\ ${ }^{2}$ Honorary member of Halberg Chronobiology Center, University of Minnesota, Minneapolis, MN, USA \\ ${ }^{3}$ Al-Farabi Kazakh National University, Almaty, Kazakhstan \\ ${ }^{4}$ Space Research Institute of RAS and Institute of Theoretical and Experimental Biophysics RAS, \\ Pushchino, Russia \\ ${ }^{5}$ Freie Universität Berlin, Berlin, Germany \\ Correspondence to: F. Halberg (halbe001@umn.edu)
}

Received: 15 December 2012 - Revised: 17 February 2013 - Accepted: 8 March 2013 - Published: 8 April 2013

\begin{abstract}
This tribute to her parents by one co-author (NDP) is the fruit of a more than a decade-long search by the senior author (FH) for the details of the lives of Bernhard and Gertraud ("Traute") Düll. These pioneers studied how space/terrestrial weather may differentially influence human mortality from various causes, the 27day mortality pattern being different whether death was from cardiac or respiratory disease, or from suicide. $\mathrm{FH}$ is the translator of personal information about her parents provided by NDP in German. Figuratively, he also attempts to "translate" the Dülls' contribution in the context of the literature that had appeared before their work and after their deaths. Although the Dülls published in a then leading journal, among others (and FH had re-analyzed some of their work in a medical journal), they were unknown to academies or libraries (where FH had inquired about them). The Dülls thoroughly assembled death certificates to offer the most powerful evidence for an effect of solar activity reflected in human mortality, as did others before them. They went several steps further than their predecessors, however. They were the first to show possibly differential effects of space and/or Earth weather with respect to suicide and other deaths associated with the nervous and sensory systems vs. death from cardiac or respiratory disease as well as overall death by differences in the phase of a common 27-day cycle characterizing these mortality patterns. Furthermore, Bernhard Düll developed tests of human visual and auditory reaction time to study effects of weather and solar activity, publishing a book (his professorial dissertation) on the topic. His unpublished finding of an increased incidence of airplane crashes in association with higher solar activity was validated after his death, among others, by Tatiana Zenchenko and
\end{abstract} A. M. Merzlyi.

\section{Preamble}

We pay an overdue tribute to Bernhard and Gertraud ("Traute") Düll, who documented an effect of solar-terrestrial weather on human mortality conceptually (Fig. 1, left section; our meta-analysis is in the right section) with thoroughly collected and analyzed data, using methods more reliable than the Pearson product-moment correlation, as is often done when dealing with periodic variables. We honor the Dülls since we found only a biographic and literary dictio- nary of the exact sciences that has only two brief and insufficient entries about them:

- (Poggendorf VIIa, 1956) Düll, Bernhard Geophysics. 1927 stud U Innsbruck, Berlin, Kiel, Rostock; 32 Dr. phil U Rostock (G. Falkenberg); 42 Doz. Geophysics \& cosmic physics U Frankfurt; on leave at this time in San Francisco/Calif., USA (his communication) Born 1908 July 3, Kuestrin. Publications are listed thereafter. 

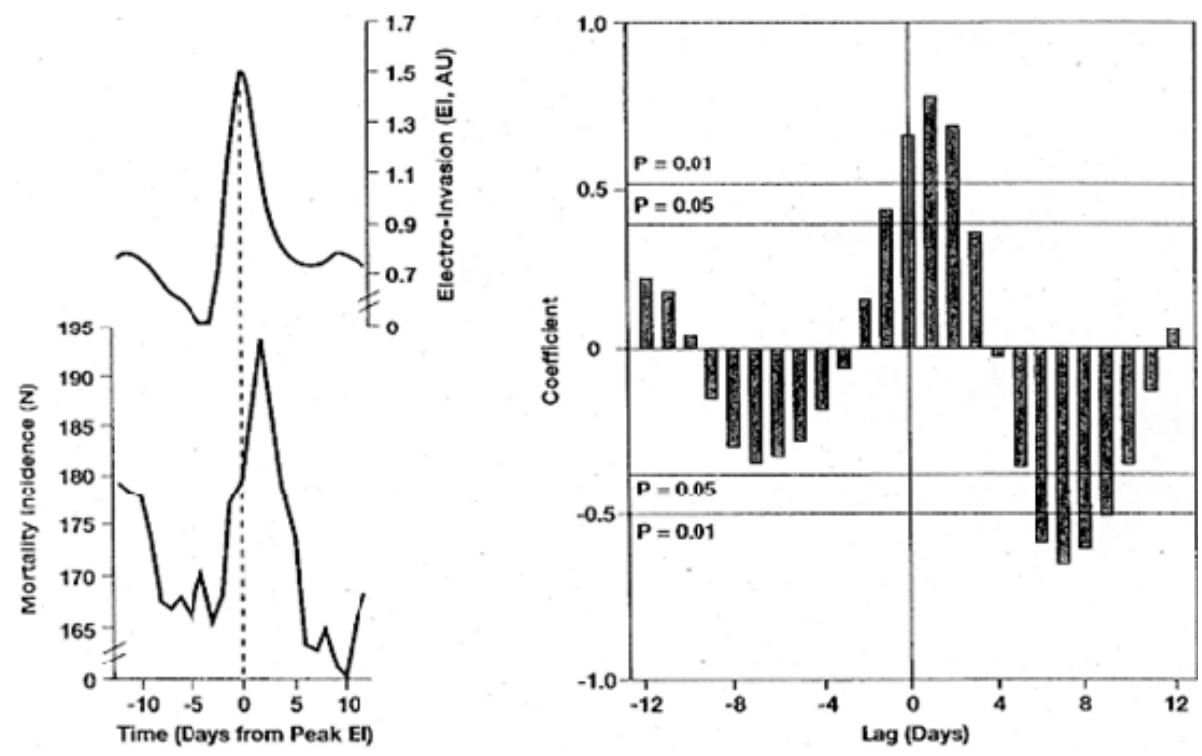

Figure 1. With data from Düll and Düll taken off their published graph (Düll and Düll, 1935a), summarizing the daily incidence of mortality from neural and mental disease and from suicides in relation to "electro-invasion" by superposed epochs over 67 solar rotation cycles between 1928 and 1932 (left), we find a maximal cross-correlation at a 1-day lag (right). By electro-invasion, the authors referred to "short-lived" eruptions on the surface of the Sun (M-regions of the Sun, presumably corresponding to what is now known as coronal mass ejections), as defined by Bartels (1932). The electrical particles ejected by these solar phenomena, when they reach Earth, elicit electron invasions, the extent of which is characterized by the extent of disturbance of the electromagnetic field. (C) Halberg.

- (Poggendorf VIII part 2 1/2 2000 lists no publications, a shorter entry \& the note that more information is not available.)

\section{Biography}

Elaborating on prior (Halberg et al., 2001a) and recent (Schwartzkopff et al., 2012) re-analyses (Fig. 1), we here present a pioneer pair of scientists, reminding us of other cooperating couples like those who co-discovered radioactivity (Pierre and Marie Curie) or gave their name to a sunspot minimum (Edward Walter Maunder and Annie Scott Dill Maunder).

Max Karl Bernhard Düll was born on 3 July 1908 in Kuestrin, Germany (now Kostrzyn, Poland), as one of nine sons of the chemist Dr. Friedrich Georg Düll and his wife Ernestine Friedericke Karoline, born Freiin von SeckendorffAberdar. Early in life he showed an interest in radio and telegraphy and more broadly in wireless communications. Throughout his life, he loved to travel. In the summer of 1926, at $18 \mathrm{yr}$ of age, he traveled by train to Constantinople (now Istanbul) and reported his experiences in the local German press.

He studied meteorology, physics, geography, astronomy and mathematics at the universities of Innsbruck, Berlin, Kiel and Rostock. He received a PhD in Rostock with the dissertation entitled, "A new theory to explain the transient appearance of nightly disturbances in wireless communications, in the context of extensive investigations of the influence of sunspots upon the atmosphere of the Earth". This topic led to his lifetime interest in how solar activity affects human physiology and pathology, a topic dealt with in broad terms by Yohsuke Kamide (2005). On the basis of measurements of disturbances presumably in radio communications, made in Abisko, Sweden, and much additional material from other parts of Europe, Traute and Bernhard Düll found an association of sunspots, geomagnetics and disturbances in radio communications on Earth, and concurrently noted the influence of solar activity exerted upon the appearance of northern lights and certain phenomena in terrestrial weather (Düll and Düll, 1934a).

In September 1932 Bernhard Düll married Gertraud (Traute) Elisabeth Auguste Mehlitz (Fig. 2), whom he had known already in Kuestrin and who had moved with her parents to Berlin, where her father was an engineer at Siemens. Traute had been educated in the arts and served in that capacity, as seen in Fig. 3 (top). As an assistant in computations and graphing, she played the role of a figurative "personal computer" in the pre-computer era (Fig. 3, bottom). In the winter of 1932-1933, the couple was in Akureyri, Iceland, observing northern lights and investigating their association with Earth's magnetism. Bernhard made measurements of visual and auditory reaction times that he believed were influenced by space/terrestrial weather, using instruments he fabricated there and subsequently (Fig. 4) (Düll, 1941). Confirmation of his work stems, in part, from our subsequent 

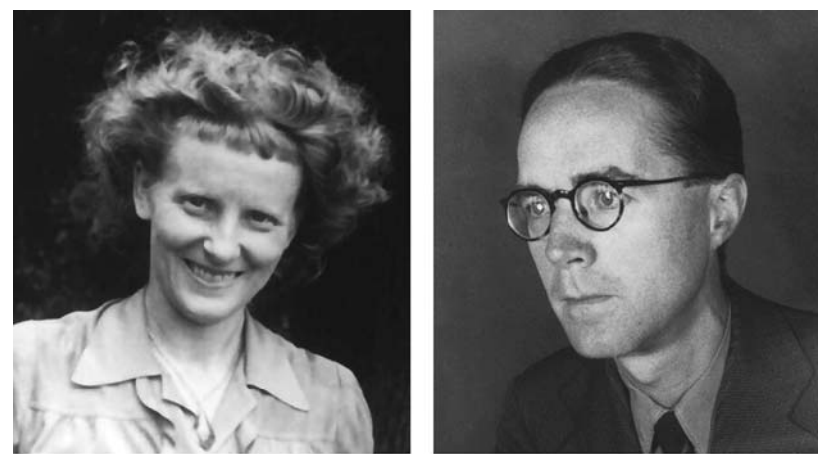

Figure 2. Traute and Bernhard Düll, a gifted couple of scientists whose early work discussed, with data stacked over 68 consecutive 27-day cycles, the differential associations of helio- and geomagnetism with mortality from mental illness vs. vascular, respiratory and overall mortality.

demonstration that the time structure (in the frequency range of 1 cycle in $2.5 \mathrm{yr}$ to 3 cycles per year) of 1 min time estimation was more similar to that of solar wind speed and that of the antipodal geomagnetic index $a a$ than the time structures of the two physical variables with each other (Fig. 5; Halberg, 2011). Meanwhile, at a time when photography left much to be desired, Traute painted the local scenery, the northern lights in particular, in watercolor at the start and in oil thereafter (Fig. 3, top).

The Dülls went to Copenhagen from April to June 1933 and to Zürich from February to April 1934 to collect and evaluate meteorological data and thousands of death certificates (Düll and Düll, 1934b), assessed in detail elsewhere (Schwartzkopff et al., 2012; cf. Halberg, 2011; Halberg et al., 2011, 2012). Their medical-statistical investigations were aligned with solar physical observations and led to thorough publications during the span from 1934 to 1941, including reviews that constitute a treasure for historians (B. Düll and T. Düll, 1938).

The data collected by the Dülls between 1 January 1928 and 31 December 1932 are displayed in Fig. 6a-c, stacked over 68 consecutive 27-day solar rotation cycles. Bartels' numbers are on the abscissa. Patterns of relative sunspot numbers (Fig. 6a, row 1) and worldwide magnetic characters (Fig. 6a, row 2) can thus be readily compared with the average daily incidence of mortality from different causes assessed separately for each day of the 27-day Bartels cycle after stacking. Patterns are shown for mortality attributed to nervous and sensory system diseases (Fig. 6a, row 3), suicides (Fig. 6a, row 4), mortality from diseases of blood circulation (Fig. 6a, row 5), and from respiratory diseases (Fig. 6a, row 6), as well as from all causes (Fig. 6a, row 7). Likewise, the 27-day pattern in auroral character (Fig. 6b, top) can readily be compared with that of cardiovascular mortality in Copenhagen (Fig. 6b, bottom), while the latter (Fig. 6c, bottom) is also aligned with cardiovascular mortal-

\section{Gertraud "Traute" Düll: artist (top) \& the personal "computer" in the pre-computer era (bottom)}
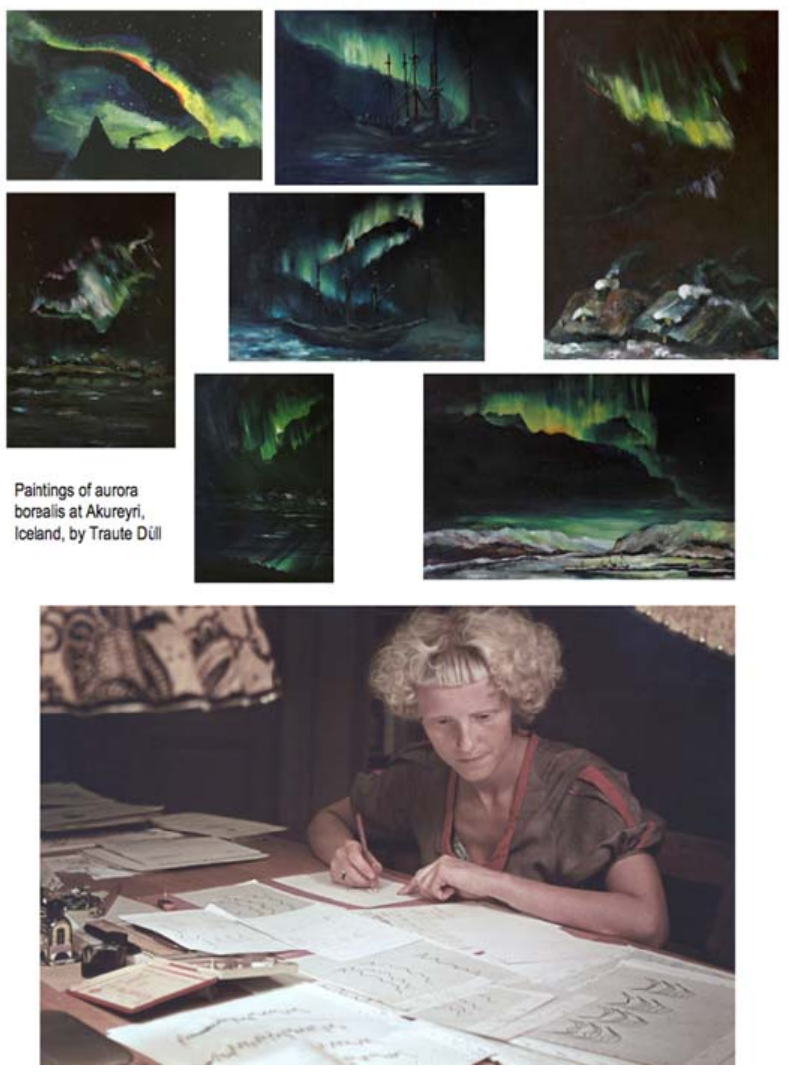

Figure 3. Northern lights in Iceland, painted by Traute Düll (top). She is also seen as an assistant carrying out computations (bottom).

ity in Zürich during the same span (Fig. 6c, top). A clear 27-day cycle can be seen by the naked eye for all variables. Maxima in worldwide magnetic characters are delayed by a couple of days while auroral character is in phase with respect to relative sunspot numbers. A similar pattern in mortality from cardiovascular disease is observed in Zürich and Copenhagen, peaking about 8 days after the maximum in solar activity. As compared to peak mortality from cardiovascular diseases, deaths attributed to nervous and sensory system diseases peak earlier and deaths from respiratory diseases peak later, as seen from dots above the curves' first maximum in Fig. 6a.

The presence of a shared about 27-day cycle in sunspots, geomagnetic activity, and mortality from various causes attests to an influence of space/terrestrial weather on human pathology. Differences in the times of maxima of the 27-day patterns of mortality from different causes indicate differences in the response from different physiological functions (different organs) to space/terrestrial weather.

Before the Dülls, in 1922, two French physicians cooperating with a physicist had also observed that the incidence of minor and grave diseases was higher at times with 


\section{Watercolors of lab apparatus painted by Traute Düll}

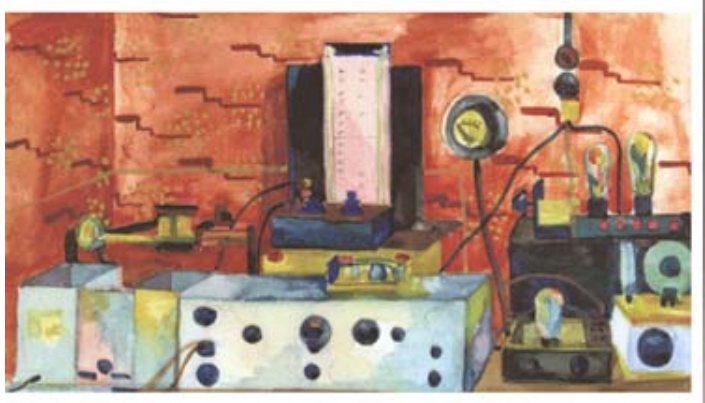

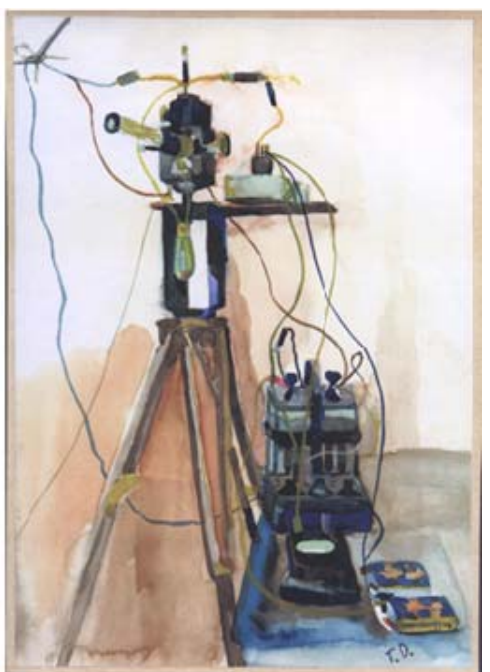

Figure 4. With the technology of his era, Bernhard Düll tried to develop a test system for human reaction time that he believed was influenced by space weather. The reason for his work is confirmed by the subsequent demonstration that human time estimation, by the criterion of shared frequencies, more than matches, in its association with either helio- or geomagnetism, the accepted association of the two magnetisms with each other (by statistically significant odds ratios, Fig. 5) (Halberg, 2011).

many sunspots (Vallot et al., 1922; Halberg et al., 2001a; Schwartzkopff et al., 2012). This is shown in Fig. 7 where chi-squared tests validated the results. Specifically, more patients sought medical advice in relation to symptoms of diseases of the heart, blood vessels, liver, kidney and nervous system on days with than on days without sunspots. Results were statistically significant whether only severe or all symptoms were considered. Those included excitability, insomnia, tiredness, aches, muscle twitches, polyuria, digestive troubles, jitteriness, shivering, spasms, neuralgia, neural crises, asthma, dyspnea, fever, pain, vertigo, syncope, high blood pressure, tachycardia, arrhythmia, and true angina pectoris. Several mechanisms have indeed been proposed to account for an effect of solar activity on the human body. Some are exerted via an influence on the weather as also shown by Bernhard Düll, others involve some form of resonant absorption, melatonin suppression and/or disturbances in neuronal signaling (Palmer et al., 2006). The Dülls properly acknowledged much prior work also by Alexander Leonidovich Chizhevsky and cited some entire paragraphs of the latter's publication (Düll and Düll, 1939a).

During the 1930s and 1940s, Bernhard Düll worked at the Institute for Meteorology and Geophysics of the University of Frankfurt (with the period 1935-1936 spent at the Kerckoff Institute in Bad Nauheim), while Traute Düll was his scientific co-worker in experimental studies, statistical computations and graphic presentations. In 1941 Bernhard Düll completed a dissertation for his habilitation entitled, "Determining reaction time to assess the influence of weather and solar activity upon humans" (Fig. 4) (Düll, 1941), thus receiving certification to lecture from the University of Frankfurt. The Dülls' classical contribution, however, is in Fig. 6a-c (Düll and Düll, 1934a). In 1942 Bernhard Düll became a lecturer (Dozent) for the Faculty of Natural Science of Frankfurt's Goethe University.

In 1944 and 1945 the Dülls were drafted by the German government to work for the Central Station for High Frequency Research of the Air Force in Leobersdorf and in Ried im Innkreis, Austria. After World War II, in March 1946 Bernhard Düll was reinstated as Dozent at Frankfurt University and was offered the position of head of that department. Instead, he accepted an offer to immigrate to the United States. Traute Düll went with him as his scientific coworker, with Fort Myer, Virginia, as their first assignment. From 1946 to 1949 the Dülls worked in the office of the Quartermaster General of the US Army in Washington, DC.

Their last publication appeared in 1948. It dealt with changes in barometric pressure related to what they call "solar particle invasions and solar ultraviolet invasions", focusing on "those different kinds of solar-radiation eruptions which are known to influence the ionosphere". "Particle invasions" are defined as being generated by eruptive processes in the so-called M-regions of the Sun (Bartels, 1932). They are not closely connected with sunspots, and "the Earth is affected by these 'invasions' only if the place of the M-regions is situated in the vicinity of that point where the line connecting the center of the Sun with the center of the Earth crosses the Sun's surface" (Düll and Düll, 1948). In data from all 9 stations examined (in De Bilt, Karlsruhe, Potsdam, Vienna, Breslau, Koenigsberg, Warsaw, Lemberg, and Kiev), the sealevel barometric pressure was lower than normal after the days when the ionosphere was particularly disturbed, with a minimum value 3 days after, and higher than normal after the 

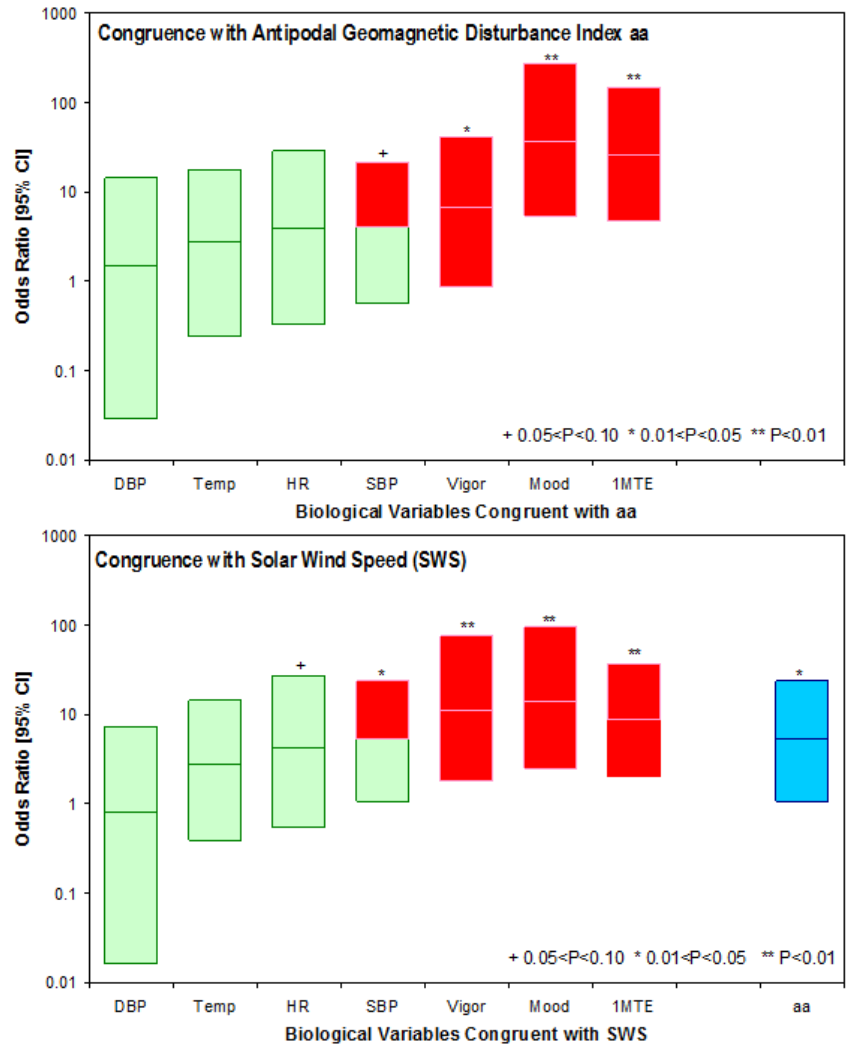

Figure 5. Some inferentially statistically validated congruences of human somatic and mental functions with the environment, gauged by the antipodal geomagnetic disturbance value ( $a a$ ) (top) and solar wind speed (SWS) (bottom). While limited to a single clinically healthy case (R.B.S., a man aging during the study from 20 to $60 \mathrm{yr}$ of age), the number of congruences found for the estimation of $1 \mathrm{~min}$ and for mood in the spectral range investigated (from one cycle in $2.5 \mathrm{yr}$ to 3 cycles per year) more than equals that of the known association of helio- and geomagnetism. When congruence is assessed by means of the odds ratio based on the noncentral hypergeometric distribution, mental functions show higher congruence than somatic functions. $P$ values are based on the noncentral Fisher hypergeometric distribution, with $95 \%$ CIs (confidence intervals) computed using Fisher's exact test. DBP: diastolic blood pressure, Temp: oral temperature, HR: heart rate, SBP: systolic blood pressure, 1 MTE: 1 min time estimation. SBP approximates higher congruence with environment of mental (red) (versus somatic, green) functions that compare favorably with congruence of $a a$ versus SWS (blue, bottom right). (c) Halberg.

days when the ionosphere was particularly undisturbed, with a maximum value 3 to 4 days after (Düll and Düll, 1948).

In 1949, the Dülls moved to San Francisco, where Bernhard worked as a private scientist and Traute became assistant preparer of exhibits at the California Academy of Sciences, where she used her artistic talent in many ways, to make illustrations, exhibits and a TV series, "Science in Action". Traute Düll's pictures of auroras prompted a special exhibit at the academy.

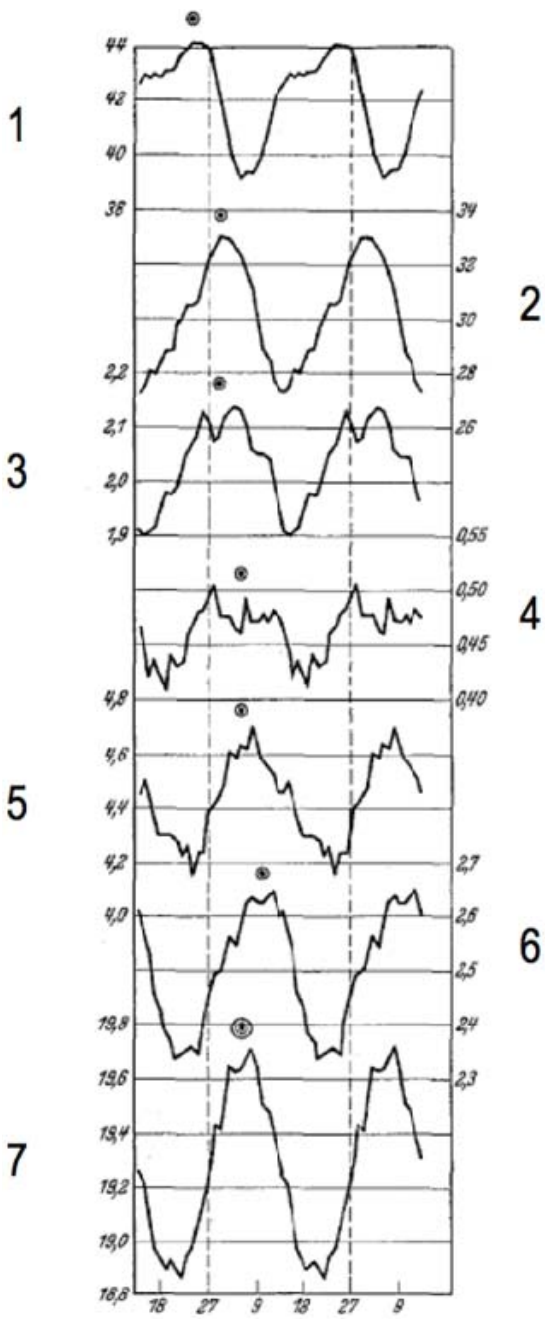

Figure 6a. Time courses during 68 stacked consecutive 27-day solar rotations in the span from 1 January 1928 to 31 December 1932, as superposed epochs for two environmental (top) and five biospheric variables (bottom; mortalities in Copenhagen), the latter showing two peaklets in rows 3 and 4 and one peak in rows 57. That the magnetisms of the Sun and the Earth differ in phase, and that so do various human mortalities, is apparent from Table 1 , from overlapping sets of CIs ( $95 \%$ confidence intervals) of the acrophases (phase of maximum of the cosine curve fitted to the data), $\varphi$ s, i.e., of peaks in 27-day cosine curves best approximating all data and providing numerical estimates of the $\varphi$ and its uncertainty. The variables are 1 . relative sunspot numbers; 2 . worldwide magnetic characters; 3.3720 deaths of children and adults $(\mathrm{C}+\mathrm{A})$ and males $(\mathrm{M})$ and females $(\mathrm{F})$ attributed to nervous and sensory system diseases; 4. 849 suicides $(\mathrm{A}, \mathrm{M}+\mathrm{F})$; 5.8099 deaths $(\mathrm{C}+\mathrm{A}$, $\mathrm{M}+\mathrm{F}$ ) from diseases of blood circulation, also including marasmus senilis $(\mathrm{A}, \mathrm{M}+\mathrm{F})$; 6.4579 deaths $(\mathrm{C}+\mathrm{A}, \mathrm{M}+\mathrm{F})$ from respiratory diseases; 7. 35244 deaths $(\mathrm{C}+\mathrm{A}, \mathrm{M}+\mathrm{F})$ from all causes (other than homicide). Dots above each curve indicate the day the maximum occurred during the Bartels cycle. From Düll and Düll (1934a). 


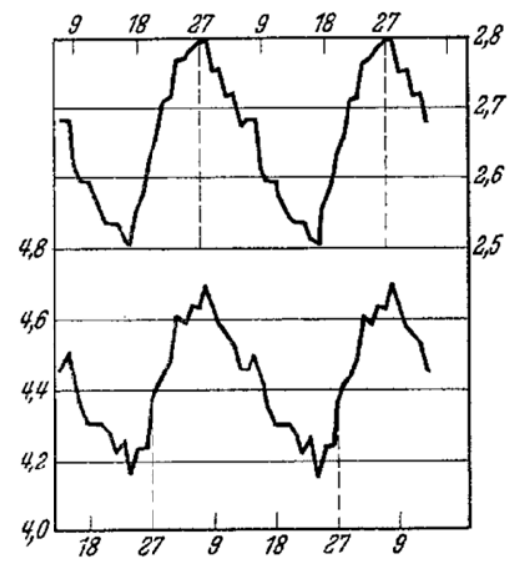

Figure 6b. Time courses during 68 stacked solar rotations between 1 January 1928 and 31 December 1932 in auroral character (top) and 8099 cardiovascular deaths of children and adults, both male and female, in Copenhagen. From Düll and Düll (1934a).

At the end of 1954, Bernhard Düll returned to Europe. Traute, who had become a US citizen, followed in November 1956. They settled near Lake Constance, with Traute first employed by the Allensbach Institute, then in 1964 taking a job with a publisher. According to their daughter, Bernhard Düll spent over 10 yr evaluating internationally recorded airplane crashes and their relation to solar activity, finding an association of the latter with an increase in the former. His unpublished results were confirmed by a subsequent study (Zenchenko and Merzlyi, 2008). Bernhard Düll died on 21 November 1983 at $75 \mathrm{yr}$ of age from a myocardial infarction. Traute Düll died on 24 April 1999 at age 90.

\section{Discussion}

The Dülls' daughter (NDP) takes credit for a German text on the life of her parents, of which much of the foregoing is an almost literal translation. NDP tells us that her father was a pacifist who, already at the start of his studies in Berlin in 1927, was part of the Universala Esperanto Asocio, a worldwide Esperanto federation for international understanding. $\mathrm{He}$ abhorred the atrocities of National Socialism and lost Jewish colleagues whom he had befriended, and lived in continuous fear of denunciation since he had held a critical distance from the Nazi regime and was a determined opponent of prescribed political rituals. Hence he took the opportunity to immigrate to the US, although he never felt quite at home there. The written German report provided by one of us (NDP) was translated by the senior author (FH). Two more of us (JF and EMF) found NDP, a task FH had pursued unsuccessfully for many years, since he re-analyzed the Dülls' data (Halberg et al., 2001a; Schwartzkopff et al., 2012).

The bibliography of the Dülls speaks best for them (Düll, 1941; B. Düll and T. Düll, 1938, 1948; T. Düll and B. Düll, 1934a, b, 1935a, b, 1936a, b, 1937a, b, 1938a-c, 1939a-d).

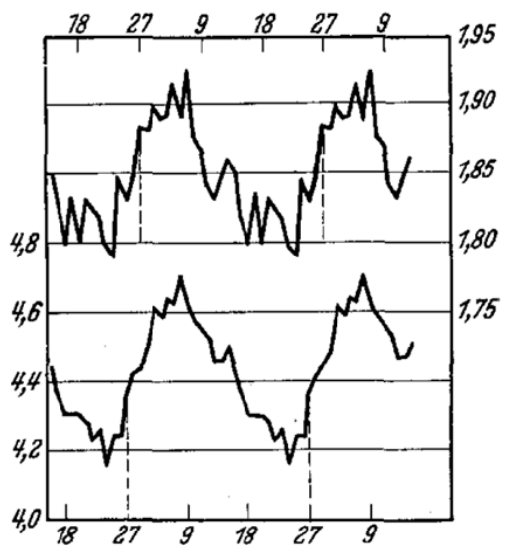

Figure 6c. Time courses of cardiovascular deaths, 3381 in Zürich (top) and 8099 in Copenhagen (bottom), during 68 consecutive, stacked, separate 27-day sections of the time series from 1 January 1928 to 31 December 1932. From Düll and Düll (1934a).

They painstakingly showed that space/terrestrial weather affected human suicide, as well as many other aspects of human mortality, as illustrated in Fig. 6a-c. It is further to their credit that they were the first to thoroughly document a difference in the 27-day cyclic mortality pattern between death from cardiac or respiratory disease or overall mortality on the one hand and death from mental disease or suicide on the other hand. This is a major step beyond the contribution of two physicians, Sardou and Faure, who with Vallot, the astronomer, meteorologist and generous supporter of research, found that severe and fatal illnesses as well as common head cold and other aches were more frequent when sunspots were numerous (Vallot et al., 1922). Their findings are illustrated in Fig. 7. Whether all or only severe symptoms are considered, our $\chi^{2}$ tests show that they occurred more often on days when sunspots were present than absent. The Dülls delved only into 27-day cycles and realized the importance of other then known periodicities.

A cycle of 27 days is well known, and many databases of space/terrestrial weather variables include a time code in terms of the 27-day Bartels cycle, even though spectral analysis of sunspots or geomagnetic indices suggests that the period may differ slightly from precisely 27 days, in keeping also with differences in solar rotation duration as a function of solar latitude. The fact that clear 27-day patterns are found by stacking over 68 consecutive cycles, the slight departure from 27 days of the exact periodicity notwithstanding, speaks for a robust rather than weak influence of space/terrestrial weather on human mortality.

The Dülls were scholars in whatever they wrote. They properly cited work done before them, referring notably to Alexander Leonidovich Chizhevsky in their papers. By 1934, their meticulous investigations established important influences of space/terrestrial weather on human mortality. For this, they focused on the Bartels cycle, using the robust 


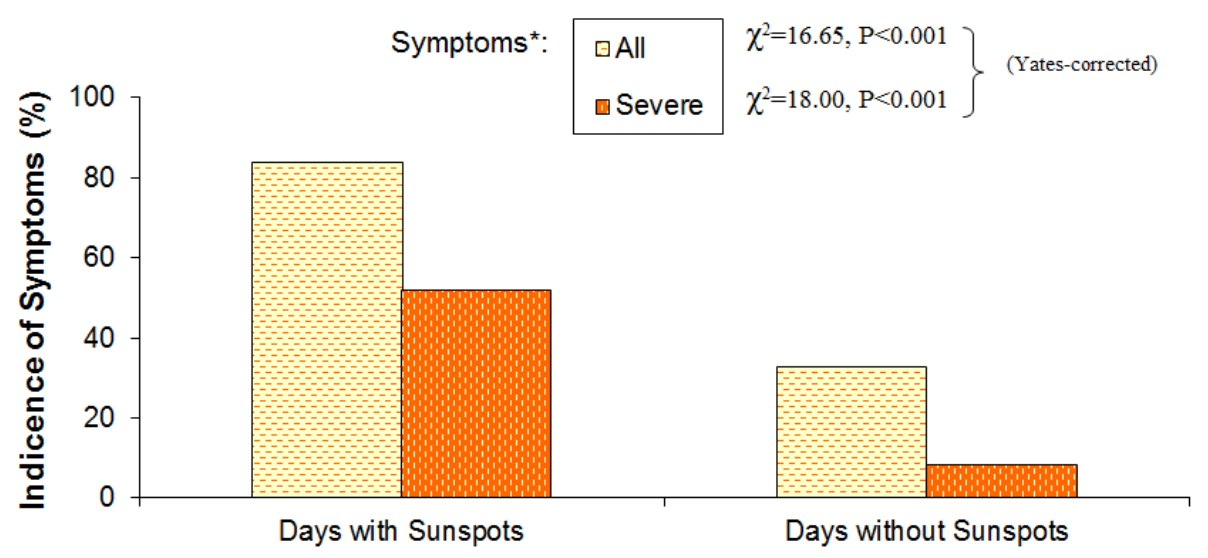

Figure 7. Analysis of what Joseph Vallot, a thoughtful physicist and philanthropist, reported as an association of symptoms with solar activity over $90 \mathrm{yr}$ ago. Specifically, the incidence of clinical symptoms of diseases of the heart, blood vessels, liver, kidney and nervous system, ranging from mild to severe (such as excitability, insomnia, tiredness, aches, muscle twitches, polyuria, digestive troubles, jitteriness, shivering, spasms, neuralgia, neural crises, asthma, dyspnea, fever, pain, vertigo, syncope, high blood pressure, tachycardia, arrhythmia, and true angina pectoris) is compared between days when sunspots were present or absent. Results from our $\chi^{2}$ tests confirm that symptoms were more likely to occur on days with than on days without sunspots, whether all symptoms or only the more severe ones (according to the original authors) were considered. Data from Vallot et al. (1922). (C) Halberg.

method of superposed epochs to analyze their data. Their contributions were in keeping with earlier work by others (Vallot et al., 1922; Sardou and Faure, 1927; Chizhevsky, 1930a, b, 1931a, b, 1934, 1976; Schostakowitsch, 1931; Faure, 1932; see also Gnevyshev and Novikova, 1972). Nevertheless, some $40 \mathrm{yr}$ later, Feinleib et al. (1975) and Lipa et al. (1976) failed to find an effect of space/terrestrial weather on the incidence of cardiovascular disease. The fact that their properly qualified negative results stemmed from abundant data, analyzed with rigorous inferential statistics, raises important questions about the periodic and nonstationary nature of the phenomena involved (Cornelissen et al., 2002; Halberg et al., 2003, 2011, 2012), and the need to better understand underlying mechanisms.

To conclude, Bernhard and Traute Düll also realized the importance of cycles in their publications, although they did not delve into most of them. In the last paragraph of their 1938 review article they wrote, "That there are very important daily rhythmic and annually rhythmic changes in the response of the human organism to exogenous physical stimuli is here only alluded to. These questions require, because of their importance for the clinician and the practical physician, an extensive special consideration." Many more patterns, i.e., a broad spectrum of cycles, characterize mortality upon analyses of Chizhevsky's data, to cite just one example (Gumarova et al., 2013). This is illustrated in Fig. 8 and Table 1, where results from re-analyses of Chizhevsky's data on diphtheria and cholera are reported and compared with those of shorter records on mortality from myocardial infarction and sudden cardiac death in several different geographic locations. In each case, the cycle's period length is shown with its $95 \%$ confidence interval (in parentheses) derived by nonlinear least squares, using Marquardt's algorithm (Marquardt, 1963).

Bernhard Düll's unpublished work on a positive association between the incidence of airplane crashes and solar activity is confirmed in Fig. 9a-c by one of us (Zenchenko and Merzlyi, 2008; cf. Zenchenko et al., 2005). In Fig. 9a, aviation accidents are plotted by superposed epochs in relation to a reversal of the interplanetary magnetic field's polarity (day 0), showing a higher incidence on days of a reversal. Similar results are shown in Fig. $9 \mathrm{~b}$ and $\mathrm{c}$ for the incidence of human (solid lines) and mechanical (dashed lines) errors in relation to a reversal of the polarity of the interplanetary magnetic field (Fig. 9b) or in relation to days of high solar wind density (Fig. 9c), maxima also observed on days of a reversal (Fig. 9b) or on days of high solar wind density (Fig. 9c). Statistical analyses of aviation incident and disaster dynamics with heliophysical factors thus show that aviation accidents are more frequent at the time of Earth's passage of sector boundaries of the interplanetary magnetic field and all times of a sharp rise of solar wind density, the phenomena that result in changing the oscillation spectrum of Earth's magnetosphere, with a sharp increase of geomagnetic activity (Schrijver and Siscoe, 2010). Other scholarly investigations of the same topic are based on correlations (cf., e.g., Stoupel et al., 2009). Correlations without considering cycles in examining associations in phenomena characterized by rhythms can be spurious, with statistically significant positive or negative correlation or no correlation found, depending solely on the phase relation between the two variables sharing the same periodicity (Fig. 10; for a review of correlations between solar activity and weather and climate, see Herman and Goldberg, 1978). Likewise, in the presence of 
Geographic differences in signatures of space and earth weather in communicable (on top) and noncommunicable (bottom) disease 1823-1926 and 1999-2003 respectively.

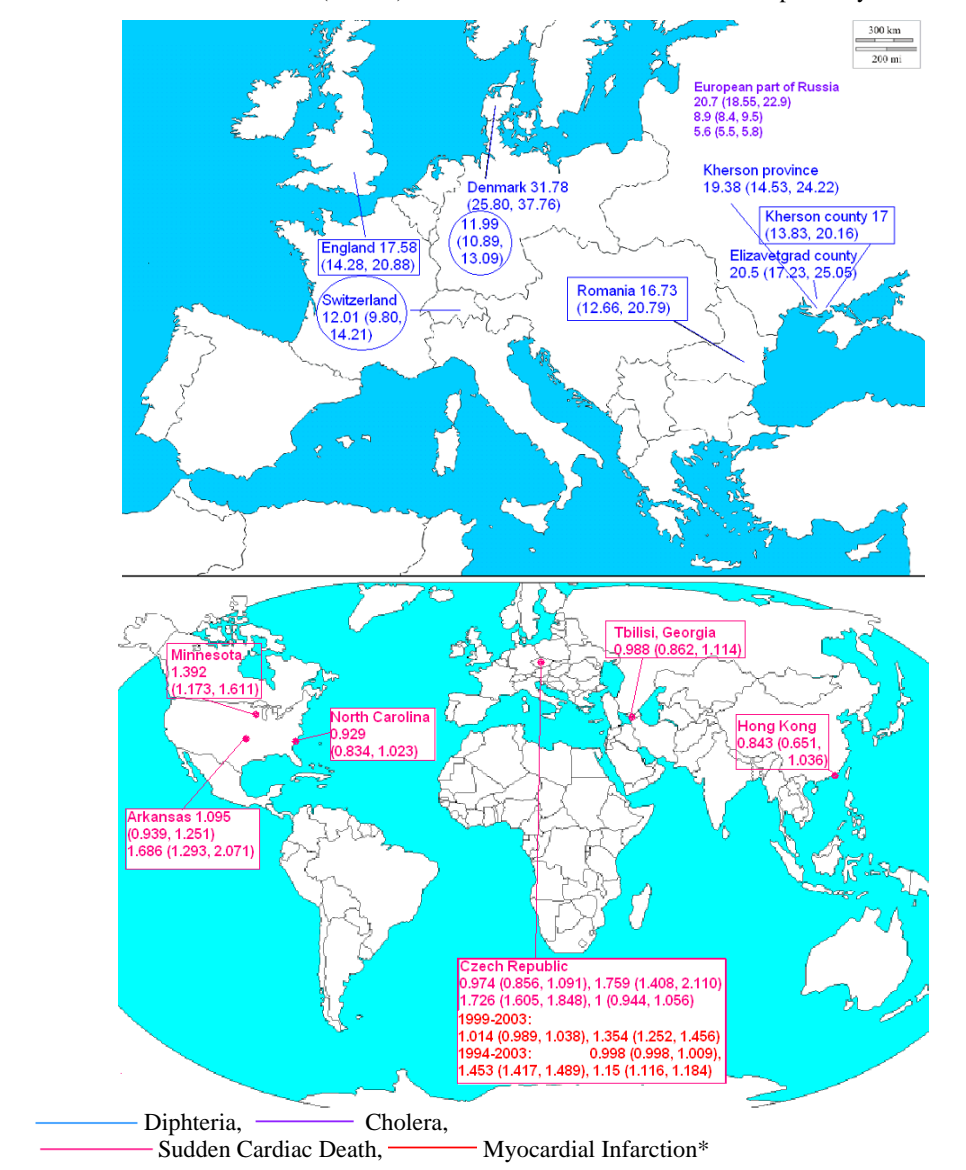

* longer observation span reveals a near-transyear, in addition to a calendar-year and a far-transyear component

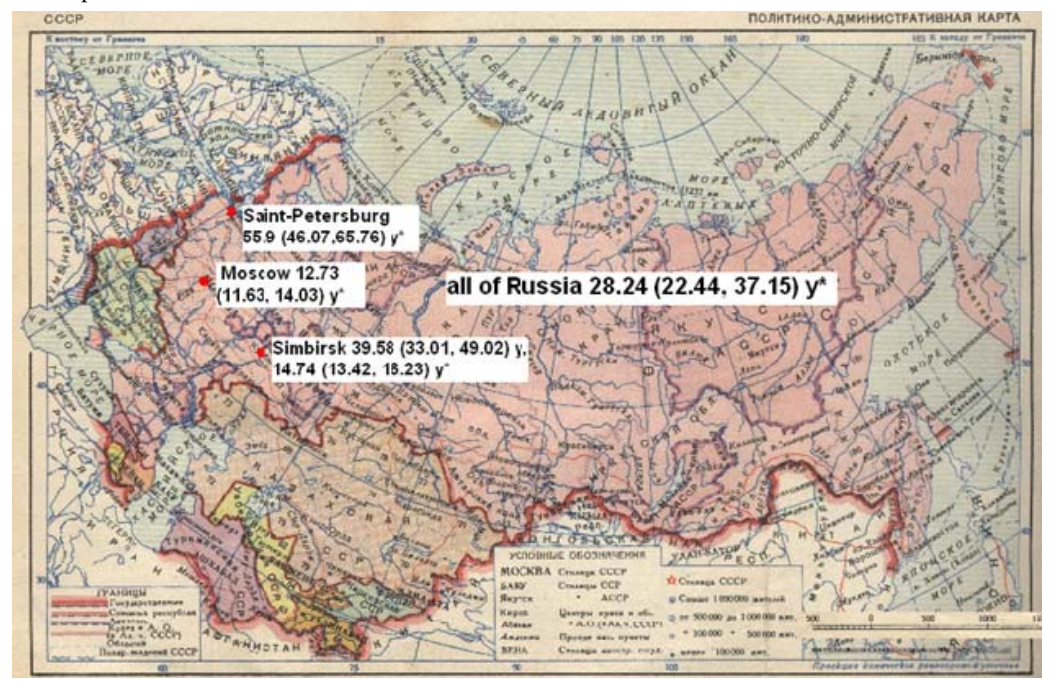

Figure 8. Many different cycles actually characterize mortality from diphtheria in Europe (top), cholera in Russia and India (middle), and overall mortality in Russia (bottom), albeit discussed by Chizhevsky as a signature of an about 11 yr cycle (top and bottom charts). Results on diphtheria and cholera data collected by Chizhevsky are compared with those on shorter records on mortality from myocardial infarction and sudden cardiac death in several different geographic locations (middle chart). In each case, the length of the cycle's period is listed with its $95 \%$ confidence interval (in parentheses) derived by nonlinear least squares. Periods are computed according to Marquardt's conservative method, except for those with an *, denoting 1-parameter limits. (C) Halberg. 
A
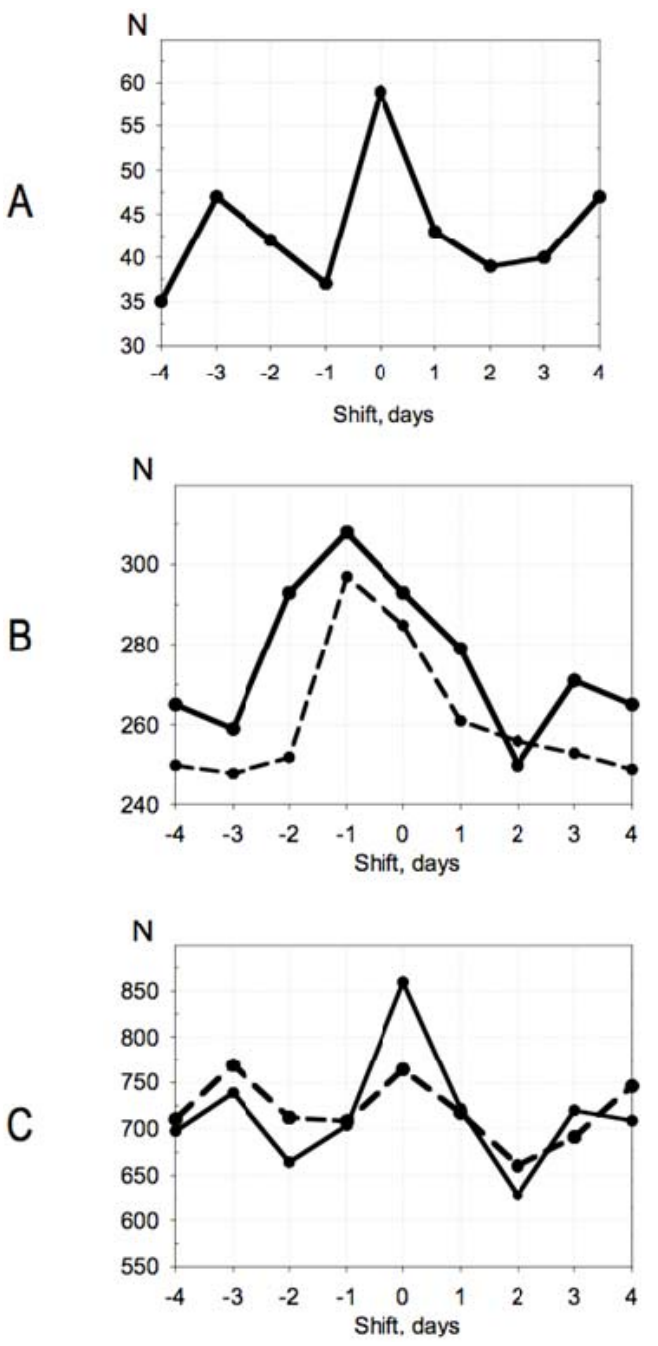

Figure 9. Superposed epochs demonstrate association of aviation accidents (A) and events due to human error (-) vs. those due to mechanical error (- - -) (B and $\mathbf{C}$ ) with reversals of the polarity of the interplanetary magnetic field (A and $\mathbf{B})$ or at high densities of solar wind speed (C). (A) Distribution of the total number of aviation accidents in the neighborhood of the times observed on Earth when the polarity of the interplanetary magnetic field (IMF) reverses during the span from 1964-2005 (Zenchenko et al., 2005). The likelihood that differences between the zero day and samples from other days are due to chance is less than $5 \%$. (C) Zenchenko. (B) Distribution of the total number of aviation events in the neighborhood of dates characterized by passage of IMF sector boundaries for the span from 1997-2005, the solid line (-) for human error, the dashed line (- -) for mechanical failure-related events (Zenchenko and Merzlyi, 2008). (C) Zenchenko. (C) Distribution of the total number of aviation events $(N)$ in the neighborhood dates of high densities of solar wind $\left(n>10 \mathrm{~cm}^{-3}\right)$ for the span from 1997-2005, the solid line (-) for human error, the dashed line (- -) for mechanical failure-related events (Zenchenko and Merzlyi, 2008). Courtesy of Tatiana A. Zenchenko. low-frequency cycles, focus on spans shorter than the period length can lead to erroneously finding statistically significant increasing or decreasing trends as a function of time (Halberg et al., 2001b). Focus on periodicity and on its uncertainties (Marquardt, 1963; Halberg, 1980) is desirable ${ }^{1}$. An association, including correlation, based on characteristics of periods may avoid blunders.

The Dülls introduced their major findings in Fig. 6a-c with a remark that in the history of science all phenomena of life on Earth have been and are determined by cosmic phenomena. They used the 27-day cycle as one of the solar signatures in the biosphere. The effects of our cosmos are nonstationary phenomena in space and time. As such, associations of human pathology with space/terrestrial weather may change in strength to the point of not being detected at certain times ("No" in Fig. 11), accounting perhaps for the failure of two large studies to find a correlation between geomagnetic disturbances and mortality in the United States (Feinleib et al., 1975; Lipa et al., 1976) (Fig. 11). In Minnesota, an about 11 yr cycle in mortality from myocardial infarction from 1968 to 1996 ( $29 \mathrm{yr}$ ) could be documented for the first two solar activity cycles but not during the third (Cornelissen et al., 2002). Since associations have been found in some studies ("Yes" in Fig. 11), even during times of minimal solar activity, we must learn from history so that we do not publish observations that may apply in one geographic location in one solar cycle, but not in other locations and/or at other times. Time-varying associations revealed by also changing phase synchronizations and coherences (Halberg et al., 2003) underlie site- and time-specific results of asyet unknown causes. Controversy can be avoided when nonstationary time- and site-specific changes are anticipated and documented in time series covering the length of several critical cycles characterizing the data. Certainly, we must consult the literature, whether or not it is in languages other than ours. We must not ignore evidence that does not fit our observations. This tribute, and others to follow, honors a pair of investigators who were unknown for many years in several (German and other) academic and other institutions, something that this and other articles, with more detailed evidence (Halberg et al., 2001a, 2013; Schwartzkopff et al., 2012), are meant to remedy.

\footnotetext{
${ }^{1}$ Marquardt's algorithm (Marquardt, 1963) provides three measures of uncertainty of the period estimate and of the other parameters of the fitted model. One is an equivalent of the usual standard error and is called the "1-parameter" approach. Another is called "conservative" in the sense that the corresponding confidence intervals are slightly wider than the "true" or "nonlinear" $95 \%$ limits. The nonlinear limits, a third measure, are more complex, but generally do not differ much from the more easily derived "conservative" approximation. In view of the non-stationarities of the biological data analyzed, the approach called "conservative" by Marquardt is actually too liberal when underlying assumptions are violated and is here used with the desire for a more appropriate method that accounts for non-stationarities and their consequences.
} 
Table 1. Geomagnetic/geographic differences among cycles with periods in the range of 5-32 yr, characterizing the incidence of infectious disease (cholera, diphtheria and croup); some periods of about $17 \mathrm{yr}$.

\begin{tabular}{|c|c|c|c|c|c|}
\hline Site & Span & Period (yr) (95\% CI) & Amplitude (95\% CI) & A $\left(\%\right.$ of MESOR $\left.{ }^{*}\right)$ & $P$ value \\
\hline \multicolumn{6}{|c|}{ Cholera } \\
\hline \multirow[t]{2}{*}{ India } & $1901-1961$ & $11.668(10.44-12.895)$ & $70.016(4.08,135.95)$ & 31 & $<0.05$ \\
\hline & & $20.71(18.55,22.88)$ & $104.79(5.69,203.89)$ & 95 & $<0.001$ \\
\hline \multirow[t]{2}{*}{ Russia } & $1823-1926$ & $8.9(8.36,9.54)$ & $78.21(28.2,128.23)$ & 71 & $<0.05$ \\
\hline & & $5.62(5.45,5.79)$ & $98.28(0.74,197.3)$ & 89 & $<0.005$ \\
\hline \multicolumn{6}{|c|}{ Diphtheria } \\
\hline Kherson province & 1874-1908 & $19.38(14.53,24.22)$ & $31.93(9.71,54.15)$ & 46 & $<0.005$ \\
\hline Kherson county & 1874-1908 & $16.996(13.83,20.16)$ & $12.54(3.42,21.67)$ & 36 & $<0.001$ \\
\hline Elizavetgrad county & 1874-1908 & $20.53(17.23,25.05)$ & $27.74(9.92,45.56)$ & 65 & $<0.005$ \\
\hline \multirow{2}{*}{ Denmark } & \multirow{2}{*}{$1860-1910$} & $31.78(25.80,37.76)$ & $43.91(19.35,68.46)$ & 66 & $<0.001$ \\
\hline & & $11.99(10.89,13.09)$ & $35.77(12.18,59.36)$ & 54 & $<0.001$ \\
\hline Prussia & $1875-1910$ & $9.10(6.63,11.58)$ & $24.27(22.14,70.68)$ & 23 & $<0.05$ \\
\hline \multirow{3}{*}{ Switzerland } & \multirow{3}{*}{$1876-1910$} & $16.98(12.76,21.2)$ & $13.04(0.04,26.04)$ & 36 & $<0.001$ \\
\hline & & $12.01(9.80,14.21)$ & $8.52(0.22,16.81)$ & 23 & $<0.001$ \\
\hline & & $26.33(18.17,34.30)$ & $11.96(0.38,24.30)$ & 29 & $<0.001$ \\
\hline \multirow[t]{2}{*}{ Scotland } & \multirow[t]{2}{*}{$1860-1910$} & $12.75(10.07,15.42)$ & $8.6(0.00,21.73)$ & 21 & $<0.05$ \\
\hline & & $9.89(8.56,11.22)$ & $9.94(0.00,23.03)$ & 41 & $<0.05$ \\
\hline \multirow{2}{*}{ Belgium } & \multirow{2}{*}{$1870-1910$} & $21.49(10.02,32.96)$ & $12.69(9.02,34.41)$ & 23 & $<0.001$ \\
\hline & & $14.02(9.27,18.78)$ & $12.71(9.08,34.50)$ & 23 & $<0.001$ \\
\hline \multirow{3}{*}{ Holland } & \multirow{2}{*}{$1875-1910$} & $14.02(9.42,18.61)$ & $6.82(0.00,17.6)$ & 27 & $<0.05$ \\
\hline & & $9.35(7.64,11.07)$ & $8.23(0.00,18.48)$ & 33 & $<0.05$ \\
\hline & & $29.37(23.15,35.59)$ & $8.89(4.06,13.73)$ & 29 & $<0.001$ \\
\hline \multirow[t]{3}{*}{ England and Wales } & \multirow[t]{2}{*}{$1860-1910$} & $17.46(14.66,20.26)$ & $7.04(1.32,12.76)$ & 23 & 0.001 \\
\hline & & $12.58(10.53,14.64)$ & $5.10(0.00,11.37)$ & 17 & $<0.05$ \\
\hline & \multirow{4}{*}{ 1864-1910 } & $24.16(10.45,37.87)$ & $3.21(2.92,9.34)$ & 14 & $<0.05$ \\
\hline \multirow{3}{*}{ Ireland } & & $17.27(7.67,26.86)$ & $2.29(4.04,8.63)$ & 10 & $<0.05$ \\
\hline & & $12.40(9.26,15.53)$ & $3.62(2.5,9.73)$ & 15 & $<0.05$ \\
\hline & & $7.84(6.54,9.15)$ & $3.42(2.76,9.59)$ & 14 & $<0.05$ \\
\hline Romania & $1886-1910$ & $16.73(12.66,20.80)$ & $9.65(2.86,16.45)$ & 49 & $<0.001$ \\
\hline Austria & $1880-1910$ & $16.09(7.55,24.64)$ & $23.66(17.58,64.9)$ & 25 & $<0.001$ \\
\hline Italy & $1887-1910$ & $12.51(2.66,22.36)$ & $9.57(14.64,33.77)$ & 28 & $<0.001$ \\
\hline France & $1889-1910$ & $11.26(7.056,15.52)$ & $13.528(0.00,30.624)$ & 51 & $<0.05$ \\
\hline \multirow{2}{*}{ Sweden } & \multirow{2}{*}{$1861-1910$} & $17.71(15.45,19.98)$ & $22.00(8.72,35.28)$ & 42 & $<0.001$ \\
\hline & & $12.58(10.16,14.99)$ & $11.89(0.00,28.14)$ & 23 & $<0.05$ \\
\hline
\end{tabular}

${ }^{*}$ MESOR: Midline Estimating Statistic Of Rhythm, a rhythm-adjusted mean, usually more precise and more accurate than the arithmetic mean.

\section{Summary}

This tribute to a pioneer pair of scientists, Bernhard and Gertraud ("Traute") Düll, illustrates the merits of a transdisciplinary approach. With a background in meteorology, physics, geography, astronomy and mathematics, and with the collaboration of his talented wife, Bernhard Düll amassed death certificates to provide solid evidence showing the influence of space/terrestrial weather on human pathology. The husband/wife pair did so by selecting the Bartels 27-day solar rotation period as a reference cycle to stack data on mortality statistics from several causes. Using superposed epoch analysis, they demonstrated a non-uniform, non-random pattern of mortality incidence. Moreover, referring to the phase of max- imal mortality incidence from various causes, they found that suicide and deaths related to the nervous and sensory systems peaked at a different stage of the Bartels cycle than mortality from cardiac or respiratory disease. Their work is placed in the broader context of similar endeavors dealing with influences of space/terrestrial weather on biota by their predecessors and the legacy they left for their followers. 


\section{Nonsense Correlations Occur when 2 Variables Share a Common Periodicity, the Correlation Coefficient Depending on their Phase Relation}

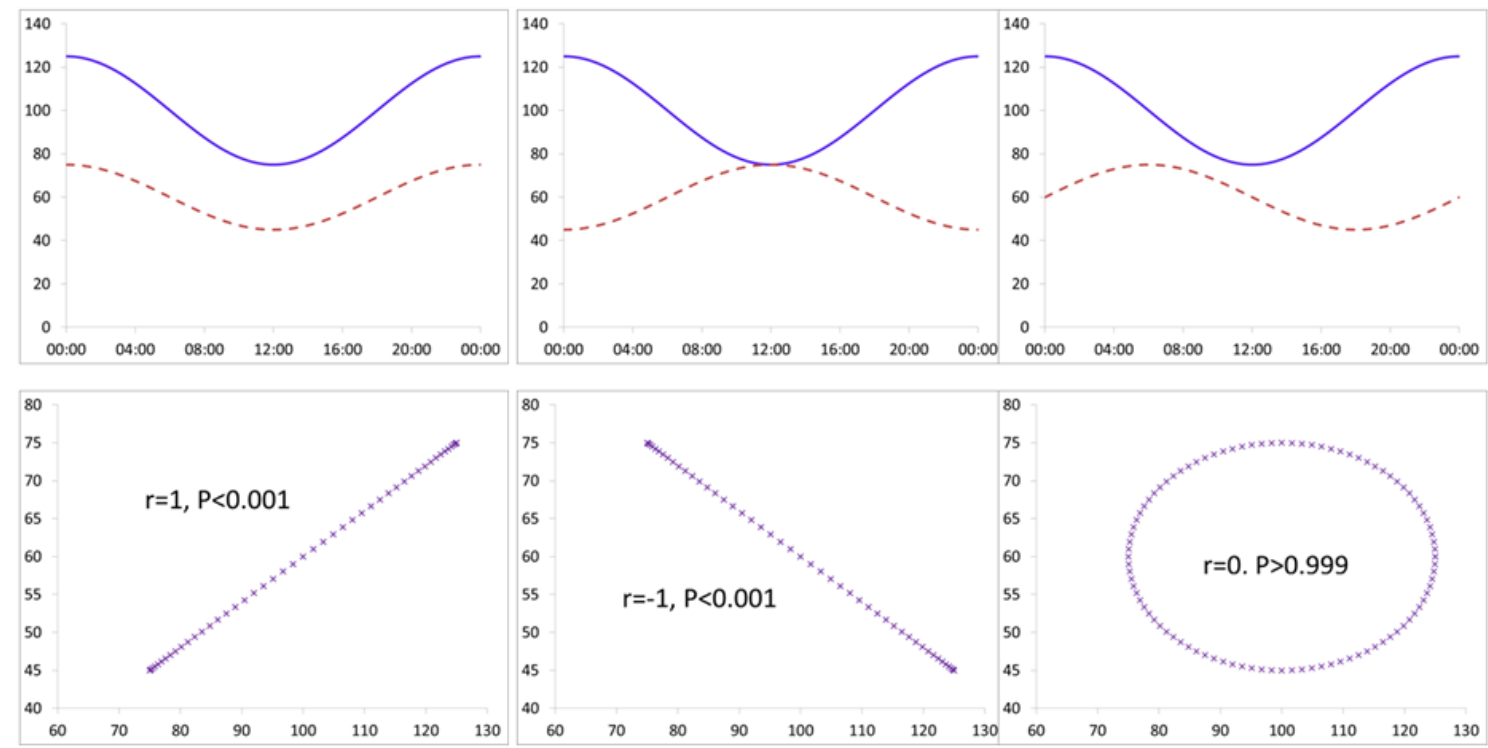

Figure 10. When two variables undergo periodic changes with the same period but different phases, the correlation coefficient yields spurious results, being positive when the two variables are in phase, negative when they are out of phase, and negligible when they are in quadrature. In such situations, the cross-correlation function should be used or other procedures that account for cycles instead of the Pearson productmoment correlation coefficient. (C) Halberg.

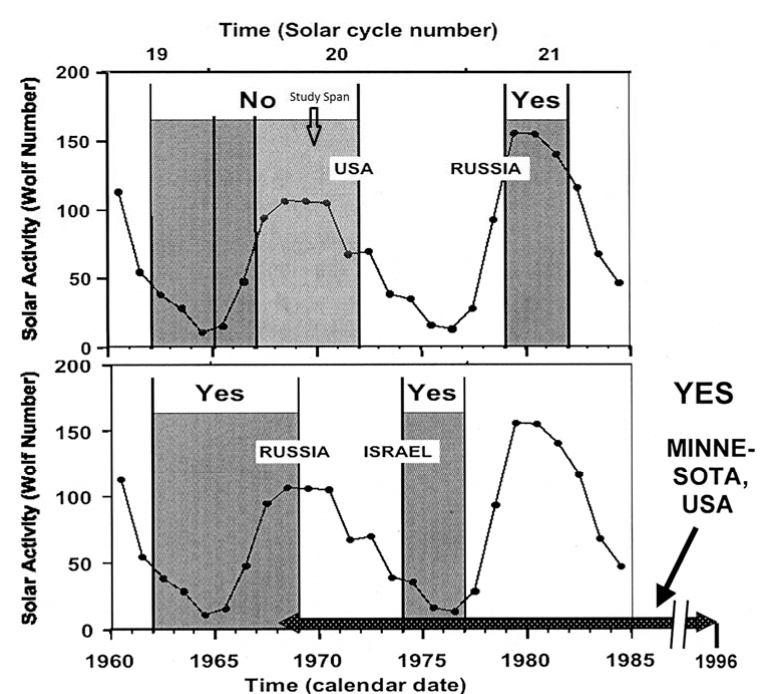

Figure 11. Top: association of magnetic storms and mortality from myocardial infarction (MI) not detected ("No") in the United States (from daily data from 1962-1966 and from only monthly data up to 1971) yet detected ("Yes") in Russia (including morbidity) during $3 \mathrm{yr}$ in 1979-1981 (Cornelissen et al., 2002) and earlier by many authors (Vallot et al., 1922; Sardou and Faure, 1927; Chizhevsky, 1930a, b, 1931a, b, 1934, 1976; Faure, 1932). Bottom: association also detected ("Yes") in 1962-1968 in Russia and in 1974-1976 in Israel, at a minimum of the Schwabe (about $10.5 \mathrm{yr}$ ) cycle, as well as in Minnesota during 1968-1996 (horizontal arrow). (c) Halberg.
Acknowledgements. The authors are indebted for thorough refereeing to Giovanni Gregori, whereby the aim of this transdisciplinary presentation toward a unified history, geography, science and art - also illustrated by the life and legacy of the Dülls - was better achieved. The paper is codedicated, by Othild Schwarzkopff, Germaine Cornelissen, Franz Halberg, the editor in chief Kristian Schlegel and his close friend, Giovanni Gregori, to the memory of Wilfried Schröder. The authors never met Wilfried in person. They appreciate that, as a historian of physics, he approached them and cooperated as a dear physicist in Germany, along with many Russian and other physicists, leading two of us to an academy of science, the Leibniz Association, with which we developed, thanks to Wilfried, stronger ties than with other national and international academies, which elected us as members.

Edited by: K. Schlegel

Reviewed by: G. P. Gregori and one anonymous referee

\section{References}

Bartels, J.: Terrestrial-magnetic activity and its relation to solar phenomena, Terr. Magn. Atmos. Electr., 37, 1-52, 1932.

Chizhevsky, A. L.: Les périodes solaires et la mortalité, La Côte d'Azur médicale (Toulon) 11, No. 9, p. 232, 1930a.

Chizhevsky, A. L.: La Natalité et la tension de l'activite solaire, La Côte d'Azur médicale (Toulon) 11, p. 2, 1930 b.

Chizhevsky, A. L.: Influences des variations de l'activité solaire sur la natalité et sur la mortalité, Bulletin de l'Académie du Var (Toulon), Vol. 98, 1931a. 
Chizhevsky, A. L.: L'activité solaire et la mortalité, Bulletin de l'Academie du Var (Toulon), Vol. 98, 1931b.

Chizhevsky, A. L.: Action de l'activité périodique solaire et sur la mortalité générale, in: Traité de Climatologie: Biologique et médicale. Tome II. Paris: Masson et Cie, edited by: Piéry, M., 1042-1045, 1934.

Chizhevsky, A. L.: The terrestrial echo of solar storms, Moscow: "Mysl", 349 pp., 1976.

Cornelissen, G., Halberg, F., Breus, T., Syutkina, E. V., Baevsky, R., Weydahl, A., Watanabe, Y., Otsuka, K., Siegelova, J., Fiser, B., and Bakken, E. E.: Non-photic solar associations of heart rate variability and myocardial infarction, J. Atmos. Sol.-Terr. Phy., 64, 707-720, 2002.

Düll, B.: Wetter und Gesundheit. Die Reaktionszeitbestimmung als Testmethode zur Feststellung von Einflüssen des Wetters und der Sonnentätigkeit auf den gesunden Menschen, in: Bernhard Düll, Wissenschaftliche Forschungsberichte Band 54, edited by: Liesegang, R. E., Verlag Theodor Steinkopff (Dresden und Leipzig), 1941.

Düll, B. and Düll, T.: Erd- und sonnenphysikalische Vorgänge in ihrer Bedeutung für Krankheits- und Todesauslösung, Nosokomeion (Vierteljahresschrift für das Krankenhauswesen), 9, 103-121, 1938.

Düll, B. and Düll, G.: The behavior of barometric pressure during and after solar particle invasions and solar ultraviolet invasions, Smithsonian Miscellaneous Collections 110 (8) (Roebling Fund), Publication 3942, 1-34, 1948.

Düll, T. and Düll, B.: Über die Abhängigkeit des Gesundheitszustandes von plötzlichen Eruptionen auf der Sonne und die Existenz einer 27tägigen Periode in den Sterbefällen, Virchows Archiv für pathologische Anatomie und Physiologie, 293, 272319, 1934a.

Düll, T. and Düll, B.: Gleichgewichtsstörungen in unserem Leben durch Eruptionen auf der Sonne, Deutsche Rundschau, 61, 161$168,1934 b$.

Düll, T. and Düll, B.: Zusammenhänge zwischen Störungen des Erdmagnetismus und Häufungen von Todesfällen, Deut. Med. Wochenschr., 3, 95-97, 1935a.

Düll, T. and Düll, B.: Neue Untersuchungen über die Beziehungen zwischen der Zahl der täglichen Todesfälle und dem erdmagnetischen Störungscharakter, Bioklimatische Beiblätter der Meteorologischen Zeitschrift, 2, 24-31, 1935b.

Düll, T. and Düll, B.: Bericht über die Frankfurter Konferenz für medizinisch-meteorologische Statistik am 30./31. März 1936, Die Naturwissenschaften, 24, 685-688, 1936a.

Düll, T. and Düll, B.: Statistik über die Abhängigkeit der Sterblichkeit von geophysikalischen und kosmischen Vorgängen, Medizinisch-meteorologische Statistik, Berlin, 197-246, 1936b.

Düll, T. and Düll, B.: Statistik über die Abhängigkeit der Sterblichkeit von geophysikalischen und kosmischen Vorgängen, Med. Welt, 7, 226-230 und 8, 263-264, 1937a.

Düll, T. and Düll, B.: Statistique sur la dépendance de la mortalité des influences géophysique et cosmiques, La Cote d'Azur Médicale, 18, 308-309, 1937b.

Düll, T. and Düll, B.: Kosmisch gelenktes Leben, Deutsche Rundschau, 64, 38-49, 1938a.

Düll, T. and Düll, B.: Les influences physiques du soleil sur les phénomènes biologiques, Biodynamisme (Paris), 3, 83-88, 1938b.
Düll, T. and Düll, B.: Zur Frage solaraktiver Einflüsse auf die Psyche, Zeitschrift für die gesamte Neurologie und Psychiatrie, 162, 495-504, 1938c.

Düll, T. and Düll, B.: Ionosphäre - Troposphäre - Biosphäre. Unsere Atmosphäre als Entstehungsort von Strahlungen, Die Umschau, 43, 605-608, 1939a.

Düll, T. and Düll, B.: Neuer Beitrag zur Erforschung des Bioklimas. Über den statistischen Nachweis solareruptiver und ionosphärischer Einflüsse auf den Menschen, Die Umschau, 43, 715-718, 1939b.

Düll, T. and Düll, B.: Meteoropathologische Anschauungen vor 120 Jahren, Bioklimatische Beiblätter der Meteorologischen Zeitschrift, 6, 197-198 und Deutsche Medizinische Wochenschrift Nr. 36, 1435, 1939c.

Düll, T. and Düll, B.: Kosmisch-physikalische Störungen des Ionosphäre, Troposphäre und Biosphäre, Bioklimatische Beiblätter der Meteorologischen Zeitschrift, 6, 65-76 und 121-134, 1939d.

Faure, M.: Sur la variabilité des manifestations rhumatismales, en relation avec les influences solaires et cosmiques, Gazette des hôpitaux 1932, 105, 1957.

Feinleib, M., Rogot, E., and Sturrock, P. A.: Solar activity and mortality in the United States, Int. J. Epidemiol., 4, 227-229, 1975.

Gnevyshev, M. N. and Novikova, K. F.: The influence of solar activity on the earth's biosphere (part I), J. Interdiscipl. Cycle Res., 3, 99-104, 1972.

Gumarova, L., Cornelissen, G., Hillman, D., and Halberg, F.: Geographically selective assortment of cycles in pandemics: Metaanalysis of data collected by Chizhevsky, Epidemiol. Infect., doi:10.1017/S0950268812002804, in press, 2013.

Halberg, F.: Chronobiology: methodological problems, Acta Medica Romana, 18, 399-440, 1980.

Halberg, F.: Lord of Time, London: Science without Borders/International Publishing House SWB, 45 pp., 2011.

Halberg, F., Cornelissen, G., Otsuka, K., Katinas, G., and Schwartzkopff, O.: Essays on chronomics spawned by transdisciplinary chronobiology: Witness in time: Earl Elmer Bakken, Neuroendocrinol. Lett., 22, 359-384, 2001a.

Halberg, F., Cornelissen, G., Watanabe, Y., Otsuka, K., Fiser, B., Siegelova, J., Mazankova, V., Maggioni, C., Sothern, R. B., Katinas, G. S., Syutkina, E. V., Burioka, N., and Schwartzkopff, O.: Near 10-year and longer periods modulate circadians: intersecting anti-aging and chronoastrobiological research, J. Gerontol. A Biol. Sci. Med. Sci., 56, M304-M324, 2001b.

Halberg, F., Cornelissen, G., Bingham, C., Witte, H., Ribary, U., Hesse, W., Petsche, H., Engebretson, M., Geissler, H.-G., Weiss, S., Klimesch, W., Rappelsberger, P., Katinas, G., and Schwartzkopff, O.: Chronomics: Imaging in time by phase synchronization reveals wide spectral-biospheric resonances beyond short rhythms ("Wenn man über kurze Rhythmen hinausgeht"), in: memoriam - lost future: Dr.-Ing. habil. Dr. rer. nat. Barbara Schack: 1952-2003, Neuroendocrinol. Lett., 24, 355-380, 2003.

Halberg, F., Cornelissen, G., McCraty, R., Czaplicki, J., and alAbdulgader, A. A.: Time structures (chronomes) of the blood circulation, populations' health, human affairs and space weather, World Heart J., 3, 73-114, 2011.

Halberg, F., Cornelissen, G., Katinas, G. S., Hillman, D., Otsuka, K., Watanabe, Y., Wu, J., Halberg, F., Halberg, J., Sampson, M., Schwartzkopff, O., and Halberg, E.: 
Many rhythms are control information for whatever we do: an autobiography, Folia Anthropologica, 12, 5-134, available at: http://ttk.nyme.hu/blgi/Knyvek\%20kiadvnyok/FOLIA\% 20ANTHROPOLOGICA/folia12.pdf, 2012.

Halberg, F., et al.: Honoring Bernhard and Traute Düll, in preparation, 2013.

Herman, J. R. and Goldberg, R. A.: Sun, weather and climate, NASA SP-426, Washington, DC, 360 pp., 1978.

Kamide, Y.: We reside in the sun's atmosphere, Biomed. Pharmacother, 59 (Suppl 1): S1-S4, 2005.

Lipa, B. J., Sturrock, P. A., and Rogot, E.: Search for correlation between geomagnetic disturbances and mortality, Nature, 259, 302-304, 1976.

Marquardt, D. W.: An algorithm for least-squares estimation of nonlinear parameters, J. Soc. Indust. Appl. Math., 11, 431-441, 1963.

Palmer, S. J., Rycroft, M. J., and Cermack, M.: Solar and geomagnetic activity, extremely low frequency magnetic and electric fields and human health at the Earth's surface, Surv. Geophys., 27, 557-595, 2006.

Sardou, G. and Faure, M.: Les taches solaires et la pathologie humaine, Presse médicale, 18, 283-285, 1927.

Schrijver, C. J. and Siscoe, G. L.: Heliophysics: Space Storms and Radiation: Causes and Effects, Cambridge University Press, Cambridge, New York, 447 pp., 2010.
Schwartzkopff, O., Düll-Pfaff, N., Cornelissen, G., Freytag, E. M., Freytag, J., Gumarova, L., and Halberg, F.: Cardiovascular/overall mortality vs. suicide differ by the Dülls' 27-day coperiodisms' phases, Proceedings, King of Organs 2012, Al Ahsa, Saudi Arabia, 18-20 November 2012, 268-269, 2012.

Schostakowitsch, W. B.: Periodische Schwankungen in den Naturerscheinungen, Gerl. Beitr. Geophys., 30, 281-335, 1931.

Stoupel, E., Babayev, E. S., Shustarev, P. N., Abramson, E., Israelevich, P., and Sulkes, J.: Traffic accidents and environmental physical activity, Int. J. Biometeorol., 53, 523-534, 2009.

Vallot, J., Sardou, G., and Faure, M.: De l'influence des taches solaires: sur les accidents aigus des maladies chroniques, Gazette des Hôpitaux, 904-905, 1922.

Zenchenko, T. A. and Merzlyi, A. M.: Relationship of the dynamics of aviation events with heliophysical processes, Geofizicheskie protsessy i biosfera, 7, 27-38, 2008.

Zenchenko, T. A., Merzlyi, A. M., Astakhov, S. A., Yanakov, A. T., Gusev, A. N., Smygov, V. A., and Levkovich, I. V.: Analysis of the statistical relationship between heliogeophysical factors and the dynamics of accidents during international flights for the period of 1947-2005, Abstracts of Papers, 6th Int. Crimean Conf. "Space and Biosphere", 39-41, 28 September-1 October 2005. 